\title{
North Atlantic right whale Eubalaena glacialis vocalization patterns in the central Gulf of Maine from October 2009 through October 2010
}

\author{
Jacqueline Bort ${ }^{1,4, *}$, Sofie M. Van Parijs ${ }^{2}$, Peter T. Stevick ${ }^{1}$, Erin Summers ${ }^{3}$, \\ Sean Todd ${ }^{1}$
}

\begin{abstract}
${ }^{1}$ Allied Whale, College of the Atlantic, 105 Eden Street, Bar Harbor, ME 04609, USA ${ }^{2}$ NOAA Northeast Fisheries Science Center, 166 Water Street, Woods Hole, MA 02543, USA

${ }^{3}$ Maine Department of Marine Resources, PO Box 8, West Boothbay Harbor, ME 04575, USA

${ }^{4}$ Present address: Science Applications International Corporation (SAIC) 2877 Guardian Lane, Virginia Beach, VA 23452, USA
\end{abstract}

\begin{abstract}
The central Gulf of Maine was recently identified as a persistent wintering ground and potential mating ground for non-calving North Atlantic right whales Eubalaena glacialis based on aerial survey data. However, these surveys were limited by bad weather and light. Here, we use passive acoustic monitoring to examine the long-term persistence of right whales in this area throughout a nearly continuous period from October 2009 through October 2010. Three archival marine acoustic recording units were deployed in the Outer Fall/central Gulf of Maine. The data were manually reviewed for right whale up-calls and gunshots to investigate seasonal and diel patterns. Up-calls and gunshots occurred seasonally, with the most calls recorded from October through January and fewer calls detected from February through July, increasing again in August through October. Up-calls were most frequent in November, and gunshots in December. There was a clear bimodal diel pattern in up-calls, with the majority of calls occurring between 04:00 through 08:00 $\mathrm{h}$ and 13:00 through 22:00 $\mathrm{h}$. There was a clear peak in diel distribution of gunshots, with the majority of calls occurring between 16:00 and 22:00 h. Our data demonstrate the continuous presence of right whales in the central Gulf of Maine during the winter months. The rate of gunshots during winter months in Outer Fall supports the hypothesis that male advertisement and/or right whale mating behavior may be taking place in this region at that time.
\end{abstract}

KEY WORDS: Right whale - Mating ground · Gulf of Maine - Passive acoustic monitoring · Seasonality $\cdot$ Diel variation

\section{INTRODUCTION}

Due to their critically endangered status, North Atlantic right whales Eubalaena glacialis (hereafter referred to as 'right whales') are arguably one of the most intensively studied large whale species (Kraus \& Rolland 2007). However, most studies have focused on habitat areas clearly identified as feeding or calving grounds, including Cape Cod and Massachusetts Bays (March-May), the Great South Channel in the

\footnotetext{
*Corresponding author: jacquelinebort@gmail.com
}

Gulf of Maine, east of Cape Cod (April-June), the Bay of Fundy and around Nova Scotia (JulyOctober), and for some of the population, the coasts of Florida and Georgia (November-May) (NMFS 2005). The first 4 of these habitats are designated as critically important feeding grounds (NMFS 2005, Ward-Geiger et al. 2005). The coast of Florida and Georgia (hereafter referred to as the 'southeast') is the only known calving ground for this species. Between 1989 and 2003, sightings of 112 female right

() Bort, Stevick, Summers and Todd 2015. Open Access under Creative Commons by Attribution Licence. Use, distribution and reproduction are unrestricted. Authors and original publication must be credited. Publisher: Inter-Research · www.int-res.com 
whales were documented in the southeast calving grounds (Browning et al. 2010), with the majority of these whales (101 of 112) observed to have calved at least once. Where the remaining portion of the population (i.e. non-pregnant females, juveniles, and adult males) overwintered and mated was unknown (Kraus et al. 1986, Kraus \& Rolland 2007) although Gaskin (1991) hypothesized that a portion of the population did not migrate in winter and instead resided in cold offshore waters where secondary plankton production would still be high.

This hypothesis was recently confirmed when large aggregations of right whales were observed during winter months in the central Gulf of Maine (Khan et al. 2010, Cole et al. 2013). Aerial surveys in the central Gulf of Maine photographed 212 individual right whales between 2002 and 2008 (Cole et al. 2013). This represents roughly half the population, based on minimum population estimates (Waring et al. 2010). Of these, 102 individuals were identified as males, including 26 known fathers, and 43 females, including 12 that gave birth the winter after their visit to the central Gulf of Maine (Cole et al. 2013); thus, Cole et al. (2013) suggest that the central Gulf of Maine may be a mating ground for the species. However, while aerial surveys provide extremely useful census and some behavioral information, they are limited by bad weather, darkness, high cost, as well as the difficulty in detecting whales during times of low density (Clark et al. 2010). Therefore, although whales have been consistently sighted during the winter in this area, little is known about their longterm presence and behavioral usage of this habitat.

Passive acoustic monitoring (PAM) does not share the same limitations as aerial survey methods and can provide longitudinal data from acoustically active species that can facilitate researchers in analyzing seasonality, call rate, and call type (e.g. Morano et al. 2012, Mussoline et al. 2012), leading to an expanded understanding of distribution, behavior and habitat preferences of the right whales. Moscrop et al. (2004) called for an extension of PAM from areas of known importance to lesser-studied areas where right whales may gather or pass through. Thus, in this study, we used PAM to supplement aerial survey findings in the central Gulf of Maine.

Most of the information that is currently known about right whale acoustic behavior has been obtained from studies in habitats of known importance such as Cape Cod Bay and the Bay of Fundy, with special focus on surface active groups (SAGs) (Matthews et al. 2001, Parks \& Tyack 2005, Clark et al. 2007, Parks et al. 2011). A SAG, defined as 2 or more animals interacting at the surface in frequent physical contact (Kraus \& Hatch 2001), is a general term that encompasses several types of social groupings involving different behavioral interactions and acoustic outputs (Parks \& Tyack 2005). Occasionally but not consistently, SAGs have been observed as a prelude to copulatory activity (Kraus \& Hatch 2001, Parks et al. 2007). SAGs have been observed in all areas where right whales have been studied, although they occur less frequently in the southeast (Kraus \& Hatch 2001, Parks et al. 2007).

Two main call types have been used to identify right whales in PAM-derived data: the up-call and the gunshot sound (Clark 1983, Parks \& Tyack 2005). The call most commonly used to identify the presence of right whales is the up-call (Clark et al. 2007). It is a stereotyped tonal sound in the 50 to $500 \mathrm{~Hz}$ range produced by all age and sex classes, and is believed to be a contact call (Clark 1982, Parks \& Clark 2007). The gunshot is a broadband and high intensity ( $>185 \mathrm{~dB}$ re $1 \mu \mathrm{Pa}$ peak-to-peak) (Parks \& Tyack 2005, Parks et al. 2012) call, which in the North Atlantic has mainly been observed in adult males and is hypothesized to be associated with social/mating or antagonistic behavior (Parks et al. 2005, 2011, 2012). Males produce these calls during social behavior (i.e. in SAGs) and in solitary bouts, which can last for several hours (Parks et al. 2005, 2012). Therefore, detection of gunshot sounds may suggest (but not exclusively) that socially directed behaviors such as male displays or SAGs are occurring.

In this study, 11 mo of near continuous marine acoustic recordings were made in the Outer Fall area of the central Gulf of Maine, a region located centrally with respect to recent winter aerial survey sightings of right whales. These data were used to assess seasonal and diel up-call and gunshot patterns.

\section{MATERIALS AND METHODS}

Three archival Marine Acoustic Recording Units (MARUs; Calupca et al. 2000) were deployed consecutively in the area where the most numerous and consistent aerial sightings of right whales have been reported by NOAA Northeast Fisheries Science Center for the central Gulf of Maine region (Khan et al. 2010) (Fig. 1). Units were deployed between October 2009 and May 2011 (Table 1) at a water depth of $168 \mathrm{~m}$.

MARUs sampled on a continuous duty cycle at a rate of $2000 \mathrm{~Hz}$ and 12 bit resolution. Hydrophone frequency response was approximately $151.2 \mathrm{~dB}$ re $1 \mathrm{~V} \mu \mathrm{Pa}^{-1}( \pm 1 \mathrm{~dB})$ in the 10 to $585 \mathrm{~Hz}$ frequency band. 


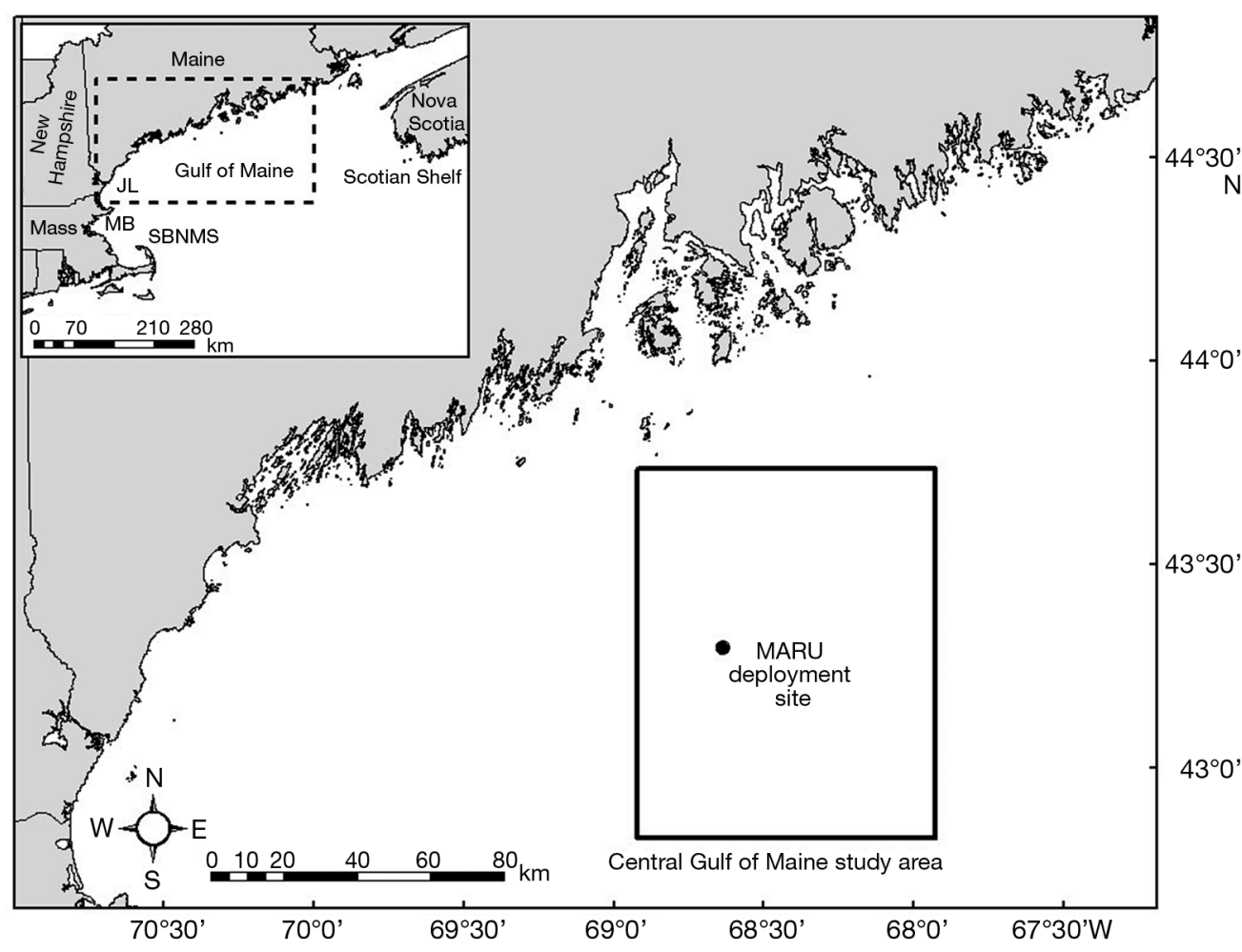

Fig. 1. Study area in the Central Gulf of Maine region based on Cole et al. (2013). (•) approximate location of all 3 marine acoustic recording unit (MARU) deployments between October 2009 and October 2010. $\mathrm{JL}=$ Jeffreys Ledge; $\mathrm{MB}=$ Massachusetts Bay; SBNMS = Stellwagen Bank National Marine Sanctuary
Table 1. Marine acoustic recording unit (MARU) location and deployment dates for the 3 consecutive deployments used in this study

\begin{tabular}{|lll|}
\hline Deployment & Location & Deployment dates \\
\hline 1 & $43^{\circ} 18.190^{\prime} \mathrm{N}$, & 30 October 2009- \\
& $68^{\circ} 37.338^{\prime} \mathrm{W}$ & 28 May 2010 \\
2 & $43^{\circ} 18.234^{\prime} \mathrm{N}$, & 29 June 2010- \\
& $68^{\circ} 37.336^{\prime} \mathrm{W}$ & 13 October 2010 \\
3 & $43^{\circ} 18.224^{\prime} \mathrm{N}$, & 13 October 2010- \\
& $68^{\circ} 37.332^{\prime} \mathrm{W}$ & 14 May 2011 \\
\hline
\end{tabular}

Logistical complications did not allow for the immediate deployment of a second MARU upon retrieval of the first MARU, so a month-long gap exists in the dataset for June 2010. Only data from October 2010 was analyzed from the third deployment to complete a 1 yr period.

\section{Data processing and analysis}

We analyzed the data primarily using the eXtensible BioAcoustic Tool (XBAT), a MATLAB (Mathworks 1997) supported open source software for sound analysis and management of large-scale acoustic data sets developed by the Cornell Bioacoustics Research Program (Figueroa 2008). Spectrograms were viewed with a Hanning window, 512 point Fast Fourier Transform (FFT), and $25 \%$ overlap.

We parsed our data by month. October 2009 only contained $2 \mathrm{~d}$ of data, so both days were analyzed. Due to the size of the dataset, data for all other months were sub-sampled, analyzing every third day of data. An automatic detector for right whale upcalls was run on all subsampled days; however, its performance was determined to be inadequate with our data (mean false positive rate: $72.38 \%$; $\mathrm{SD}=$ 32.57). As a result, the same data were manually analyzed for gunshots and up-calls. This allowed analysts to review the up-call detections made by the detector and correct for false positives and negatives. All days from October 2009 through March 2010, as well as 14 September 2010 through October 2010 were processed by the same analyst. A team of 13 analysts assisted with data from April 2010 through September 2010. All logs created by these analysts were then validated by the original analyst.

There are currently no clear criteria for distinguishing right whale up-calls from similar calls made by humpback whales Megaptera novaeangliae (Mussoline et al. 2012). Humpback whale song was detected almost every day from November through December 2009, which is consistent with other findings from high latitude areas in winter (Vu et al. 2012). As a precautionary strategy, whenever an up-call was 
detected during a sequence of humpback whale song or within 15 min preceding or following a humpback whale call, we classified the detection as a false positive, thus removing it from the final dataset. Humpback whale upsweeps typically occur in sequences containing other frequency-modulated call types that have stronger harmonics than right whale calls (Payne and McVay 1971, Mellinger et al. 2007, Mussoline et al. 2012), while right whale calls occur in bouts with longer and less regular inter-call intervals than humpbacks (Matthews et al. 2001, Mussoline et al. 2012). Through aural and visual analysis, we were able to confidently determine when humpback vocalizations were present in the recordings and thus exclude them from call analyses. This approach was similar to the method described in Mussoline et al. (2012).

The total number of calls per day and per month were determined for both call types for all days analyzed. The mean daily number of calls was calculated for each month. In order to examine diel patterns, the total number of both call types per hour for each day was calculated and then averaged by number of calls per hour by month.

October 2009 and June 2010 were removed from the dataset for statistical analysis so that only complete months were represented (however these data are included otherwise to indicate whale presence/absence). Both daily and hourly call rates were log-transformed to ensure normal distribution for statistical analysis. Post hoc analyses used the Bonferroni correction to preserve Type I error. In total, analysis was performed on 114 d of data between October 2009 and October 2010.

\section{RESULTS}

\section{Call seasonality}

Pooling all months of recordings, up-calls were the most numerous call type detected $(\mathrm{n}=31115)$. Gunshots were not observed as frequently as up-calls but were still numerous ( $\mathrm{n}=$ 18639). It bears repeating that this magnitude of call observation is de- rived from only subsampling every third day. Of $114 \mathrm{~d}$ analyzed, there were no days where only gunshot calls were present without up-calls; however, there were $20 \mathrm{~d}$ where up-calls were present but no gunshots were detected. No right whale vocalizations were detected on 39 of those days. Both call types were seasonally distributed, with the most calls recorded from October 2009 through January 2010 and fewer calls detected from February through April 2010. No calls were detected in May 2010. Calls increased again from July through October 2010. The month with the highest number of detections of each call type was November 2009 for up-calls ( $\mathrm{n}=$

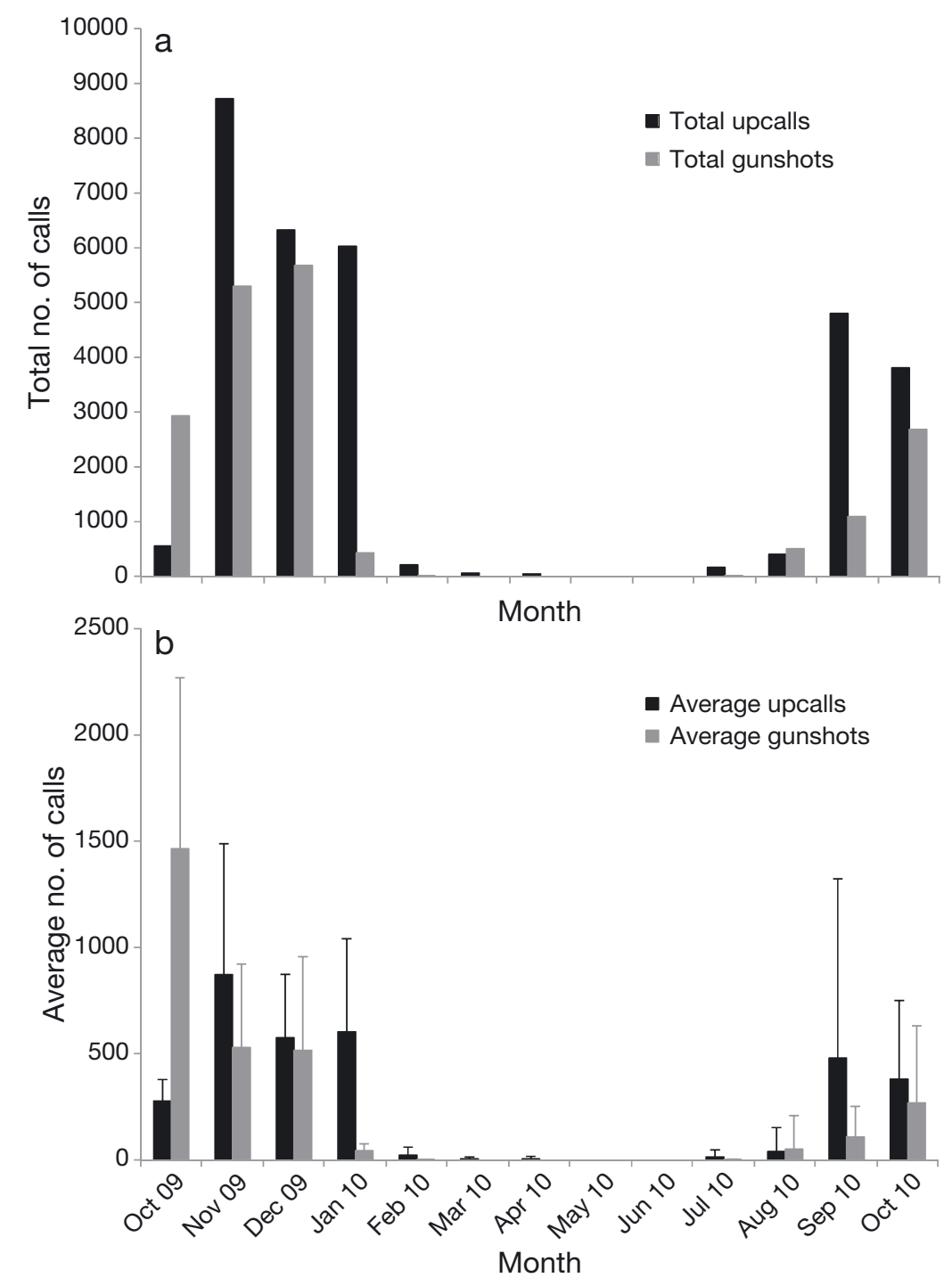

Fig. 2. (a) Total number of North Atlantic right whale Eubalaena glacialis upcalls and gunshots each month from October 2009 through October 2010; (b) mean daily number of right whale up-calls by month from October 2009 through October 2010 versus mean daily number of gunshots by month + SE. For both (a) and (b), October 2009 does not represent complete effort due to timing of marine acoustic recording unit (MARU) deployments 
8719; Fig. 2a) and December 2009 for gunshots ( $=$ 5680; Fig. 2a). Other potential right whale call types were observed and are described in Bort (2011).

When the mean daily call rate was calculated for each month, up-calls were highest from October 2009 through January 2010 (Fig. 2b), with the highest mean daily call rate occurring in November $\left(F_{9,63}=\right.$ 9.77, $\mathrm{p} \leq 0.001$ ). This was followed by a decrease in mean daily call rate from February through April. Very few up-calls were detected in July. Mean daily call rate began to increase again in August through September. Post hoc analyses confirmed that April, February, March, and July had significantly fewer calls than November, December, and January.

Mean daily call rate for gunshots was high from October 2009 through December 2009. The mean daily call rate for gunshots in January and February was comparatively much lower than in previous winter months $\left(F_{7,44}=5.37, \mathrm{p} \leq 0.0001\right)$, again confirmed through post hoc comparisons. No gunshots were detected from March through May, and production rate was very low $(n=13)$ in July. Mean gunshot rate then increased steadily from late August through the end of October 2010.

\section{Diel patterns}

There was a bimodal pattern to up-calls, with peaks in mean hourly call rate per hour from 04:00 to 08:00 $\mathrm{h}$ and 13:00 to 22:00 $\mathrm{h}$, and fewer from 09:00 to 12:00 $\mathrm{h}$ and 23:00 to 03:00 $\mathrm{h}$ (Fig. 3). The mean call rate for gunshots showed a small peak from 24:00 through 03:00 $h$, and then dropped off followed by a strong peak at 16:00 through 19:00 $\mathrm{h}$, remaining high until 22:00 h (Fig. 4).

Hourly call rate was significantly different between hours of the day for both up-calls $\left(F_{23,852}=1.97 \mathrm{p}=\right.$ $0.0044)$ and gunshots $\left(F_{23,534}=5.6 \mathrm{p}=0.0001\right)$. There was no statistical interaction between month and hour on mean hourly rate of up-calls or gunshots. Post hoc criterion indicated that hours later in the day (high call rate) were significantly different from midday hours (low call rates).

\section{DISCUSSION}

\section{Call seasonality}

Right whale call rates were highest in fall and winter months. Although the dataset was subsampled every $3 \mathrm{~d}$, right whale calls were present for every day analyzed between 30 October 2009 through 8 February 2010, and again from 27 August 2010 through 29 October 2010. Up-call detections were high despite a conservative bias due to the removal of likely right whale calls that occurred around humpback whale calls or song. Up-calls were most frequently observed in November, remaining high in December and January then decreasing into April. Right whales were not detected in May, but were detected again in July, and the number of calls increased subsequently. Since whales were detected on every day analyzed within a nearly 4 mo dataset, it is possible that a considerable number of whales were congregating specifically in this area, although it should be noted that repeat detection of the same individual(s) is possible and likely occurred for bouts of calls of similar amplitudes within each day, and possibly across days. However, visual data (Khan et al. 2010, 2011, Cole et al. 2013) from the same years and time period confirm substantial numbers of sightings within and outside of the recording area. Aerial surveys photographed 129 unique individual right whales out of 152 animals photographed in the Jordan Basin/Outer Fall area from November 2009 through February 2010 (NOAA Northeast Fisheries Science Center unpubl. data). When aerial and visual data are considered together, the high detection rate of right whale presence indicates that this region is an important habitat that is persistently used.

The highly seasonal nature of gunshot sound detections within this study supports the hypothesis that this call peaks seasonally (Parks et al. 2005, 2012, Van Parijs et al. 2009). In the North Atlantic, mature male right whales have been observed producing gunshot sounds during SAGs and in solitary bouts (Parks et al. 2012). These solitary bouts averaged $1.5 \mathrm{~h}$ but sometimes exceeded $7 \mathrm{~h}$ in duration (Parks et al. 2012), and have been compared to secondary sexual displays observed in other species (Parks et al. 2005, 2012). Bouts of gunshots that appeared to be consistent with Parks et al. (2012) due to their temporal patterning and similarity in amplitude were observed but not specifically analyzed. However, the rate of gunshots during winter months in the Outer Fall supports the hypothesis that male advertisement and/or mating behavior may be taking place in this region at that time.

The findings of this study are particularly useful within the context of other acoustic studies performed in neighboring regions. Considered together, these studies begin to form a picture of right whale movement within the Gulf of Maine during the winter. Recent acoustic studies suggest that whales 

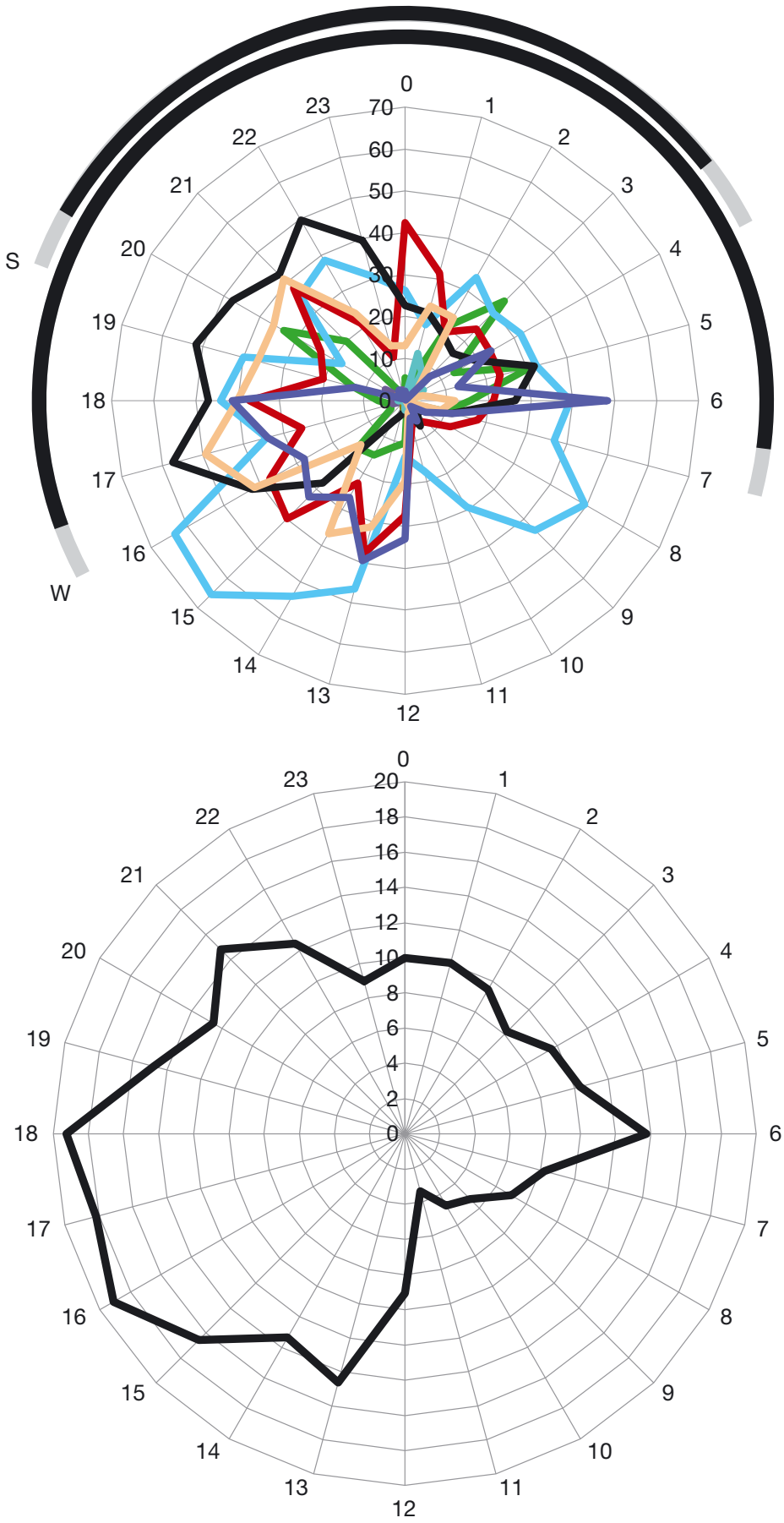

Fig. 3. Eubalaena glacialis. (a) Average up-call diel timing by month from October 2009 through October 2010, and (b) up-call average for the entire year. October 2009 and June 2010 do not represent complete effort due to timing of marine acoustic recording unit (MARU) deployments. The hour of the day is shown on the outer circle and the number of calls per hour is shown on the spokes. The outer 2 lines in (a) show the darkness (black) and twilight (grey) times for the summer (S) and winter (W) solstices using data obtained from the US Naval Observatory Astronomical Applications website (http://aa.usno.navy.mil). The most prominent months are Oct 09 in green, Nov 09 in light blue, Dec 09 in red, Jan 10 in black, Sep 10 in beige, and Oct 10 in dark blue. Aug 10 has a small peak in calling visible at 01:00 $\mathrm{h}$ in turquoise

\begin{tabular}{|l|}
\hline Oct $09-$ \\
Nov 09 \\
Dec 09 \\
Jan 10 \\
Feb 10 \\
Mar 10 \\
Apr 10 \\
May 10 \\
Jun 10 \\
Jul 10 \\
Aug 10 \\
Sep 10 \\
Oct 10 \\
\hline
\end{tabular}

spend time feeding in the Great South Channel and southern Gulf of Maine with peak use in April, then move to the Bay of Fundy, Roseway Basin and other Canadian waters to feed in late summer and fall (Mellinger et al. 2007, Clark et al. 2010, Mussoline et al. 2012, Morano et al. 2012). While some adults migrate south to calving grounds in Florida and Georgia (Kraus 1990, Brown et al. 2001), a number of whales, most likely non-pregnant females and adult males, begin in September to move from the Bay of Fundy to the Outer Fall, where they remain throughout the winter, sometimes spreading out into adjacent habitats such as Jeffreys Ledge, or Cashes Ledge (Khan et al. 2011). The winter habitat may encompass all surrounding habitats, centered around the Outer Fall region.

For example, a study of up-calls from 2 locations on the Scotian Shelf was conducted from July 2004 through August 2005 (Mellinger et al. 2007). This study recorded its highest up-call daily rates from August through October, with sporadic calls recorded in November and December. No calls were recorded in January. These data suggest that at least some whales are present through fall and into early winter, reflecting an overall southward trend in habitat use as winter progresses.

A similar study was conducted on Jeffreys Ledge over a 7 mo period from November 2004 through May 2005, and at Stellwagen Bank National Marine Sanctuary (hereafter referred to as Stellwagen Bank) from January 2006 through February 2007 (Mussoline et al. 2012). Up-calls were highest in Stellwagen Bank in January through March with a peak in April, then decreased in May with no or few calls detected in July through December. Upcalls at Jeffreys Ledge peaked in November, remaining high through March, with calls decreasing through May. The seasonal pattern of calls detected in the current study in the Outer Fall region is similar to that at Jeffreys Ledge. However, more up-calls were detected at Outer Fall 


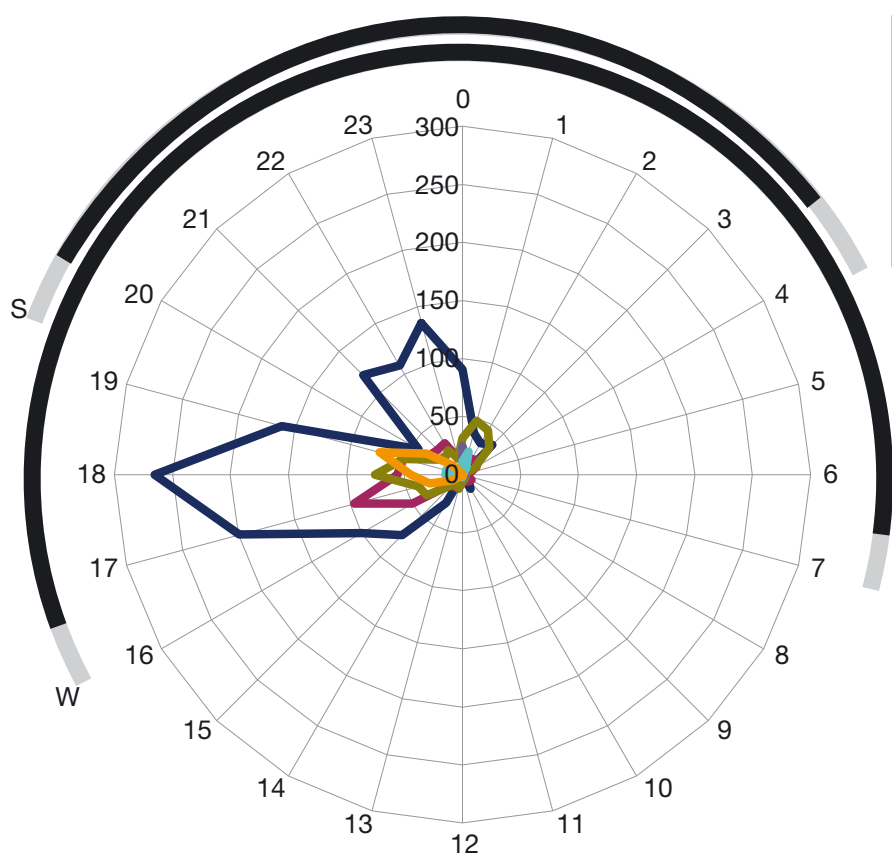

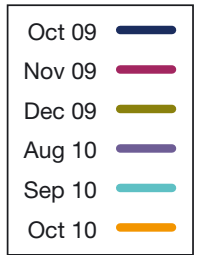

( $\mathrm{n}=31115$ ) using a single MARU from 13 mo of subsampled data than on Jeffreys Ledge ( $\mathrm{n}=26988)$ using 4 buoys (and therefore a more extensive range) from a fully analyzed $7 \mathrm{mo}$ deployment, indicating more whales at the Outer Fall location. A third study, using $3 \mathrm{yr}$ of PAM from Massachusetts Bay found that right whale calls were most abundant from February through May (Morano et al. 2012), further suggesting that whales move from the central Gulf of Maine to Massachusetts Bay as winter progresses.

The findings for the Outer Fall region correspond well with the findings from Stellwagen Bank and Massachusetts Bay when viewed as adjacent habitats that whales may utilize for different reasons depending on the time of year. Call rates between these habitats seem to mirror known right whale distributions, provided these studies are detecting multiple animals. However, it should be noted that our current knowledge of winter acoustic behavior of right whales in the Gulf of Maine comes from a variety of studies conducted between 2 and 4 yr apart, and it is possible that shifts in right whale distribution among the areas studied have occurred. We do not have a good understanding of the factors that influence right whale distribution, which may be driven inter alia by interannual changes in oceanographic conditions, prey abundance, and prey distribution.

\section{Diel patterns}

The results from Jeffreys Ledge and Stellwagen Bank (Mussoline et al. 2012) closely resemble those from Outer Fall. However, the results from the present study differ slightly from diel patterns for Massachusetts Bay. In months with low vocal activity (June through January), Morano et al. (2012) reported no strong diel pattern for up-calls. However, in the Outer Fall there was a strong bimodal distribution in upcalls, and a very strong peak in gunshots between 16:00 and 22:00 h. This clear pattern supports the idea that the central Gulf of Maine may have a more specific behavioral function during these months than Massachusetts Bay, causing the whales to call at more regular time periods. Massachusetts Bay likely serves as a migration corridor in winter between Cape Cod
Fig. 4. Eubalaena glacialis. (a) Average gunshot diel timing by month from October 2009 through October 2010. Gunshots were detected in February and July 2010 but are not shown due to low etection rate. (b) Gunshot average over the entire year. October 2009 and June 2010 do not represent complete effort due to timing of marine acoustic recording unit (MARU) deployments. The hour of the day is shown on the outer circle and the number of calls per hour is shown on the spokes. The outer 2 lines in (a) show the darkness (black) and twilight (grey) times for the summer (S) and winter (W) solstices using data obtained from the US Naval Observatory Astronomical Applications website (http://aa. usno.navy.mil) 
Bay and central Gulf of Maine habitats such as the Outer Fall.

Right whale vocalizations appear to increase during times when foraging efficiency is low (Parks et al. 2012), likely due to the vertical migration of copepods in the late afternoon hours (Baumgartner \& Mate 2003). A similar bimodal diel distribution for gunshots was reported in the Bay of Fundy during July and August (Parks et al. 2012), and Roseway Basin during August through November (Matthews et al. 2014). The bimodal distribution of calling in Outer Fall and other high latitude habitats suggests that whales that remain in these areas during winter months likely engage in foraging in addition to reproductive behavior.

\section{Insight from aerial surveys}

Aerial survey data support the idea that the distribution of right whales in these late fall and early winter habitats is tied to mating. Aerial survey data from the central Gulf of Maine were collected from November through January from 2002 to 2008 (Cole et al. 2013). Generalized linear models showed that significantly higher proportions of conceptive females (females giving birth the following year) and known fathers were present in the central Gulf of Maine compared to other seasonally important habitats during the months of November through January (Cole et al. 2013). This is consistent with acoustic data for this region.

Aerial surveys observed 11 SAGs in the central Gulf of Maine from November 2009 through February 2010 (NOAA Northeast Fisheries Science Center unpubl. data). While $47 \%$ of observed SAGs involve an adult female and male where copulation could occur (Parks et al. 2007), the timing of most observed SAGs (spring, summer, and fall) does not correlate with current data on the estimated gestation periods, births, and birth intervals of right whales (Kraus \& Hatch 2001, Parks \& Tyack 2005, Parks et al. 2007). Thus, SAGs are thought to serve a variety of purposes beyond conception (Parks et al. 2007). Calves are born between December and February, after an estimated 12 to 13 mo gestation period (Kraus \& Hatch 2001); therefore, conception should take place in the same months a year earlier, assuming no delayed implantation. This is a reasonable estimate, given that the gestation time for the closely related southern right whale Eubalaena australis is between 11.7 and 13.0 mo (Best 1994). The rate of SAGs in southern right whales increases during what is believed to be the mating period (Best et al. 2003), so it has been hypothesized that SAGs should continue into December in the northern population (Parks et al. 2007). Thus, it is likely that SAGs taking place in winter months lead to conception in some female right whales (Cole et al. 2013). This hypothesis is supported by the acoustic data presented here, including gunshots - a call produced primarily by male whales most likely for the purpose of social or reproductive display.

\section{CONCLUSIONS}

This study utilized MARUs to detect the presence of right whales in a newly discovered winter habitat that may also serve as a mating ground. Acoustic data were analyzed to determine seasonal and diel patterns for 2 known right whale calls - the up-call and the gunshot sound. The rates of both signals varied throughout the year, with the majority of calling taking place during the fall and winter months. There was a clear bimodal pattern in the diel distribution of up-calls, and a clear peak in diel distribution of gunshots.

The data presented here complement results from studies conducted in surrounding habitats that, when combined, create a more complete understanding of right whale winter distribution. While this study cannot definitively assign the Outer Fall region of the Gulf of Maine as a mating ground, our data show that the central Gulf of Maine/Outer Fall is a seasonally important habitat for right whales, with potentially high levels of male display/mating behavior. This habitat should be incorporated into future management strategies for this species.

Acknowledgements. We gratefully acknowledge the College of the Atlantic Acoustics Program volunteers (N. Ramirez, J. McCordic, M. Klein, S. Golaski, C. Spagnoli, L. Nielson, A. Brett, Y. Takemon, A. Pierik, R. Sullivan-Lord, P. Onens, Y. Bowen, and B. Beblowski) for their help with analysis. We thank Sarah Mussoline and Denise Risch for their assistance during the course of this project. Tim Cole, Christin Kahn, and Allison Henry from NOAA Northeast Fisheries Science Center provided valuable insight from their aerial surveys of the study area. We also thank Dave Sinclair, Trent Quinby, Dan DenDanto and Toby Stephenson of Allied Whale, and Jason Michalec of Cornell Bioacoustics Research Program for their assistance with MARU deployment logistics. Helpful comments were provided by Susan Barco, Cara Hotchkin, Anne Kozak, Ron Filipowicz, and Steven Thornton. Funding for this project was provided by the Maine Department of Marine Resources, NOAA grants NA09NMF4520418 and NA10NMF4520291, and the Maine Space Grant program. 


\section{LITERATURE CITED}

Baumgartner MF, Mate BR (2003) Summertime foraging ecology of North Atlantic right whales. Mar Ecol Prog Ser 264:123-135

Best PB (1994) Seasonality of reproduction and the length of gestation in southern right whales, Eubalaena australis. J Zool (Lond) 232:175-189

Best PB, Schaeff CM, Reeb D, Palsbøll PJ (2003) Composition and possible function of social groupings of southern right whale in South African waters. Behaviour 140: 1469-1494

Bort JE (2011) Acoustic behavior of North Atlantic right whales in a potential winter mating ground: implications for management of human activity. MPhil thesis, College of the Atlantic, Bar Harbor, ME

Brown MW, Brault S, Hamilton PK, Kenney RD and others (2001) Sighting heterogeneity of right whales in the western North Atlantic: 1980-1992. J Cet Res Manag (Spec Issue 2):245-250

Browning CL, Rolland RM, Kraus SD (2010) Estimated calf and perinatal mortality in western North Atlantic right whales (Eubalaena glacialis). Mar Mamm Sci 26:648-662

Calupca TA, Fristrup KM, Clark CW (2000) A compact digital recording system for autonomous bioacoustic monitoring. J Acoust Soc Am 108:2582-2582

> Clark CW (1982) The acoustic repertoire of the southern right whale, a quantitative analysis. Anim Behav 30: 1060-1071

Clark CW (1983) Acoustic communication and behavior of the southern right whale (Eubalaena australis). In: Payne $\mathrm{R}$ (ed) Communication and behavior of whales: AAAS Selected Symposium No. 76. Westview Press, Boulder, CO, p 163-198

Clark CW, Gillespie D, Nowacek DP, Parks SE (2007) Listening to their world: acoustics for monitoring and protecting right whales in an urbanized ocean. In: Kraus SD, Rolland RM (eds) The urban whale. Harvard University, Cambridge, MA, p 333-357

Clark CW, Brown MW, Corkeron P (2010) Visual and acoustic surveys for North Atlantic right whales, Eubalaena glacialis, in Cape Cod Bay, Massachusetts, 20012005: management implications. Mar Mamm Sci 26: 837-854

Cole TVN, Hamilton P, Henry AG, Duley P, Pace RM III, White BN, Frasier T (2013) Evidence of a North Atlantic right whale Eubalaena glacialis mating ground. Endang Species Res 21:55-64

Figueroa H (2008) XBAT extensible bioacoustic tool, v.5. Bioacoustics Research Program, Cornell Laboratory of Ornithology, Ithaca, NY. http://xbat.org/ (accessed Jan 2009)

Gaskin DE (1991) An update on the status of the right whale, Eubalaena glacialis, in Canada. Can Field Nat 105: 198-205

Khan C, Cole T, Duley P, Glass A, Gatzke J (2010) North Atlantic right whale sighting survey (NARWSS) and right whale sighting advisory system (RWSAS) 2009 results summary. Northeast Fish Sci Cent Ref Doc No. 10-07. National Marine Fisheries Service, Woods Hole, MA

Khan C, Cole T, Duley P, Henry A, Gatzke J (2011) North Atlantic right whale sighting survey (NARWSS) and right whale sighting advisory system (RWSAS) 2010 results summary. Northeast Fish Sci Cent Ref Doc No. 11-05. National Marine Fisheries Service, Woods Hole, MA
Kraus SD (1990) Rates and potential causes of mortality in North Atlantic right whales (Eubalaena glacialis). Mar Mamm Sci 6:278-291

Kraus SD, Hatch JJ (2001) Mating strategies in the North Atlantic right whale (Eubalaena glacialis). J Cet Res Manag (Spec Issue 2):237-244

Kraus SD, Rolland RM (2007) Right whales in the urban ocean. In: Kraus SD, Rolland RM (eds) The urban whale. Harvard University Press, Cambridge, MA, p 1-38

Kraus SD, Prescott JH, Knowlton AR, Stone GS (1986) Migration and calving of right whales (Eubalaena glacialis) in the western North Atlantic. Rep Int Whal Comm 10:139-144

Mathworks (1997) Using MATLAB. The Math Works, Natick, MA. www.mathworks.com/ (accessed Jan 2009)

Matthews JN, Brown S, Gillespie D, Johnson M and others (2001) Vocalization rates of the North Atlantic right whale (Eubalaena glacialis). J Cetacean Res Manag 3: 271-282

> Matthews LP, McCordic JA, Parks SE (2014) Remote acoustic monitoring of North Atlantic right whales (Eubalaena glacialis) reveals seasonal and diel variations in acoustic behavior. PLoS ONE 9:e91367

Mellinger DK, Nieukirk SL, Matsumoto H, Heimlich SL and others (2007) Seasonal occurrence of North Atlantic right whale vocalizations at two sites on the Scotian Shelf. Mar Mamm Sci 23:856-867

> Morano JL, Rice AN, Tielens JT, Estabrook BJ, Murray A, Roberts BL, Clark CW (2012) Acoustically detected yearround presence of right whales in an urbanized migration corridor. Conserv Biol 26:698-707

Moscrop A, Matthews J, Gillespie D, Leaper R (2004) Development of passive acoustic monitoring systems for northern right whales. Can Acoust 32:17-22

Mussoline SE, Risch D, Hatch LT, Weinrich MT and others (2012) Seasonal and diel variation in North Atlantic right whale up-calls: implications for management and conservation in the northwestern Atlantic Ocean. Endang Species Res 17:17-26

National Marine Fisheries Service (2005) Recovery plan for the North Atlantic right whale (Eubalaena glacialis). National Marine Fisheries Service, Silver Spring, MD

Parks SE, Clark CW (2007) Acoustic communication: social sounds and the potential impacts of noise. In: Kraus SD, RM Rolland (eds) The urban whale. Harvard University, Cambridge, MA, p 310-357

Parks SE, Tyack PL (2005) Sound production by North Atlantic right whales (Eubalaena glacialis) in surface active groups. J Acoust Soc Am 117:3297-3306

Parks SE, Hamilton PK, Kraus SD, Tyack PL (2005) The gunshot sound produced by male North Atlantic right whales (Eubalaena glacialis) and its potential function in reproductive advertisement. Mar Mamm Sci 21:458-475

Parks SE, Brown MW, Conger LA, Hamilton PK and others (2007) Occurrence, composition, and potential functions of North Atlantic right whale (Eubalaena glacialis) surface active groups. Mar Mamm Sci 23:868-887

Parks SE, Searby A, Celerier A, Johnson MP, Nowacek DP, Tyack PL (2011) Sound production behavior of individual North Atlantic right whales: implications for passive acoustic monitoring. Endang Species Res 15:63-76

Parks SE, Hotchkin CF, Cortopassi KA, Clark CW (2012) Characteristics of gunshot sound displays by North Atlantic right whales in the Bay of Fundy. J Acoust Soc Am 131:3173-3179 
Payne RS, McVay S (1971) Songs of humpback whales. Science 173:585-597

- Van Parijs SM, Clark CW, Sousa-Lima RS, Parks SE, Rankin S, Risch D, Van Opzeeland IC (2009) Management and research applications of real-time and archival passive acoustic sensors over varying temporal and spatial scales. Mar Ecol Prog Ser 395:21-36

Vu ET, Risch D, Clark CW, Gaylord S and others (2012) Humpback whale song occurs extensively on feeding

Editorial responsibility: Louise Chilvers, Wellington, New Zealand grounds in the western North Atlantic Ocean. Aquat Biol 14:175-183

Ward-Geiger LI, Silber GK, Baumstark RD, Pulfer TL (2005) Characterization of ship traffic in right whale critical habitat. Coast Manag 33:263-278

Waring GT, Josephson E, Maze-Foley K, Rosel PE (eds) (2010) US Atlantic and Gulf of Mexico marine mammal stock assessments. NOAA Tech Memo NMFS-NE- 219, Northeast Fisheries Science Center, Woods Hole, MA

Submitted: March 31, 2014; Accepted: September 30, 2014 Proofs received from author(s): December 3, 2014 